\title{
The Political Significance of Burial and Remembrance
}

\author{
Lauren K. Hall
}

Published online: 21 May 2011

(C) Springer Science+Business Media, LLC 2011

If it be easy to see that it is more particularly important in democratic ages that spiritual opinions should prevail, it is not easy to say by what means those who govern democratic nations may make them predominate.

Alexis de Tocqueville

Sophocles' Antigone begins with the problem of burial. Creon has dictated that "no man may hide in a grave nor mourn in funeral, but leave unwept, unburied..." the "unhappy corpse of Polyneices", Antigone's brother. Antigone vows to bury her brother, thus setting off a tragic chain of events. Sophocles' focus on burial is hardly singular; the Greeks were no strangers to the moral weight of our dealings with the dead. From the dragging of the corpse of Hector to Medea's theft of her children's bodies so Jason could not bury them, the Greeks understood the significance of burial rites. Moreover, the political implications of burial were clear to the Greeks. The rites of burial were both sacred on the one hand, binding the this-worldly to the other-worldly, and yet simultaneously used for political purposes on the other, to threaten and reward political enemies and friends, as demonstrated by Creon's decision in Antigone.

Americans share this Greek preoccupation with burial rites, which we inherited from our British forbears. From

L. K. Hall ( $\bowtie)$

Department of Political Science,

Rochester Institute of Technology,

92 Lomb Drive,

Rochester, NY, USA

e-mail: 1xhgpt@rit.edu the vast national cemetery at Arlington to the first municipal cemeteries like Mount Hope in Rochester, NY, to tiny ancient cemeteries like that housing the Huguenots of New Paltz, NY, cemeteries are an ever present reminder of those who came before. Since the start of the wars in Iraq and Afghanistan, we've seen caskets draped in flags, acres of tombstones stretching out into the distance, and even discussions of the importance of buglers in military funerals. Ted Kennedy's burial in Arlington demonstrates the connection between devotion to public service and our desire that such devotion be memorialized after death. The burial of soldiers and veterans brings out our most solemn patriotism, our most humane reflections. Yet, our national obsession with burial rites (and it isn't just ours. Princess Diana's funeral was watched by 1.5 billion people worldwide) has a grotesque side as well. Celebrity deaths like Michael Jackson's, costing upwards of $\$ 700,000$ for internment alone, remind us of Evelyn Waugh's biting commentary on the American approach to death in The Loved One. Whispering Glades, Waugh's take on Hollywood cemeteries, is counterfeit, shallow, and delusive, and eventually its hollowness (paralleled by the deception of suitors and advice columnists alike) engulfs its heroine, Aimee. Her experience with the American brand of death is, of course, a metaphor for the American experience as a whole. The British poet Dennis's callous dispassion (and eventual return to Britain) saves him from the combination of American faux sentimentality and corresponding capitalistic ruthlessness that dooms his predecessor, Sir Francis, and that is so wonderfully represented in the Whispering Glades Memorial Park.

Whispering Glades reflects the somewhat paradoxical attitudes toward burial in our society, reflecting the conflict between the emotional and the rational aspects of humanity. 
In the first place, we recognize the power of the tragic, and we find ourselves unreflectively bowing down before the eternal. The dead encourage respect, and the unreflective nature of that feeling can lead us to somewhat grotesque and maudlin ceremonies (at Whispering Glades, even a viewing becomes farcical, as Joyboy brings a suicided corpse in, announcing, "Here is the strangulated Loved One for the Orchid Room"). On the other hand, the embalming of the dead and their burial in concrete vaults can strike our rationalistic faculties as wasteful and irrational. The growth of "green burials", while still a tiny subset of burials, indicates that more people are questioning the necessity of ensconcing oneself in lead and concrete for eternity. The green burial folks, however, are hardly immune to the weight of tradition and the unreflective respect for traditional forms of burial. The Green Burial Council stresses in its discussion of embalming that, "The Council doesn't think any end-of-life ritual or disposition option is "wrong'". The Council merely wants to "ensure that services/products are available to people who wish to minimize their environmental impact". Thus, even critics of our current methods of burial cannot be actual critics, because any criticism of the way we bury our dead drives against the long-standing power and emotional weight of tradition, and of a tradition with a peculiarly powerful weight.

Despite some growth in "green" disposal of the dead, Americans are unlikely to do away with their habits of burial altogether, and at least part of this unwillingness demonstrates hidden strands in the American character that can be traced back to our roots, including the covenant theology of our Christian colonies and the intergenerational compact of the aristocracy we claimed to have rejected during our revolution. These two strands of religion and history tend to temper the democratic nature of American life, and this tempering can be seen in the role that cemeteries and graveyards play in the formation of American character. Cemeteries bind us to the past, remind us of the intergenerational compact we are all part of, and, most importantly for democracies, temper the sovereignty of the present generation, limiting the progressivism inherent in democratic discourse. Thus, cemeteries reflect a counter to the isolating individualism and cult of youth that capitalistic democracies foster; in this way, cemeteries are a physical reminder of hidden theoretical strands in the American psyche. As this physical reminder, cemeteries may operate as a kind of canary for our democratic coal-mine; when we stop caring for the dead, both physically and metaphorically, our transformation into the last-man so feared by Nietzsche will be complete. We find a similar warning in Tocqueville: "The proper object therefore of our most strenuous resistance, is far less either anarchy or despotism than the apathy which may almost indifferently beget either the one or the other".

\section{The Current State of Burial and its Philosophic Origins}

American burial rites seem to be changing, though data is hard to come by. The growth of cremation, on pace to be preferred by $40 \%$ of the population by 2010 , might indicate that our love affair with eternal internment may be coming to an end. Yet people are still using cemeteries in droves. While nation-wide statistics are sparse, Jeffrey Simmons, the manager of the Riverside and Mount Hope Cemeteries in the city of Rochester, NY, indicates that at least at those cemeteries, demand is the same as it ever was, but that the usage of cemeteries is changing. More people are choosing columbariums or other ways of memorializing themselves, and Riverside Cemetery has plans in place for a "scattering garden", which includes a "memorialization wall". Mount Hope Cemetery alone houses almost 400,000 "permanent residents" (thus larger in numbers than Arlington National Cemetery), and Riverside Cemetery to the north houses another 250,000 . While we change what we do with our bodies after death, our desire to be remembered and memorialized persists.

Tocqueville would not be surprised by the American love of memorialization. On the one hand, his commentary on democracy might lead one to believe that Americans would be peculiarly unattached to ancient burial rites, and would be unsentimental about what to do with the bodies of their dearly departed. Tocqueville notes that, "America is therefore one of the countries in the world where philosophy is least studied, and where the precepts of Descartes are best applied". Our inherent Cartesianism means that Americans look to themselves for answers to questions, since they lack both the time for philosophy and the social hierarchy that in more traditional societies provides answers in the form of tradition: "Thus they [Americans] fall to denying what they cannot comprehend; which leaves them but little faith for whatever is extraordinary, and an almost insurmountable distaste for whatever is supernatural." How can this peculiarly Cartesian mindset explain the American love of death ritual? Tocqueville refers us away from philosophy (and its political offspring, democracy) to religion. Tocqueville's view of Americans is similar to Waugh's; we are split by our founding, and our split personality makes its home in the separation of religion from politics. The "activity of individual analysis" inspired by the individualistic life of Americans is tempered and "restrained within narrow limits" by the Christian tradition: "In the United States religion is therefore commingled with all the habits of the nation and all the feelings of patriotism; whence it derives a peculiar force". 
Moreover, because religion has stayed separate from politics (in the narrow sense), religious tradition maintained its force in the face of political change. While we may occasionally question our burial habits, more often than not we simply accept them at face-value, as the habits and customs given us by our religion. This resistance to change has its effects on policy; the EU's 2007 ban on formaldehyde, the primary ingredient in embalming fluids has been slow to catch on in the U.S. (not surprisingly, the Irish, who love their wakes, have protested). The U.S., for geographic and cultural reasons, has been largely impervious to environmental and conservationist arguments to change the way we bury the dead.

\section{The Political Significance of Cemeteries}

While the social importance of cemeteries may be clear, the political importance of cemeteries is often overlooked. Cemeteries accomplish three primary, though unintended, goals in political life, and these goals are particularly important for democratic communities. In the first place, cemeteries represent the intergenerational compact best laid out by Edmund Burke. Second, cemeteries moderate the sovereignty of the present generation supported by democracy by forcing us to recognize the past as limiting present generations. Finally, cemeteries "particularize history" by providing us with a window into the lives of men, women, and children, which counters both history's tendency to generalize and liberalism's tendency to erase individual characteristics in the name of universal human rights.

Cemeteries and grave-yards alike help to elucidate the often misunderstood difference between compact and contract. One of Tocqueville's major concerns about democratic character was its lack of connection to the past. Aristocracy, by binding us through bloodlines to specific people, places, and ways of life, centered around the "intergenerational compact" between past, present, and future. Society, for aristocratic thinkers, was not a contract between individuals, as Locke and Hobbes would have us believe, but instead a compact between generations (and ultimately, God), and this compact limits the sovereignty of the present generation. Tocqueville argues, "In the midst of the continual movement which agitates a democratic community, the tie which unites one generation to another is relaxed or broken; every man readily loses the trace of the ideas of his forefathers or takes no care about them". Democracy is the most mobile of political regimes, a mobility that takes both vertical and horizontal forms. Just as we were separated from our ancestors in the Old World, we continued this trend by our inexorable move to the west. The history of America is in large part a history of migration. More than movement across geographic space, democracies also represent mobility of social class, the vertical mobility that allows people to separate themselves from the historic ways of life of their ancestors.

Each kind of mobility has the tendency to separate us from the past. Geographic mobility separates us from our present families and past ancestors, while class mobility separates us from the way of life of those who came before. Separation from both family and past tends to support the radical individualism that Tocqueville saw as closely linked to despotism, and this radical individualism is further supported by social contract thinkers like Locke and Hobbes. Locke in particular grounds political communities in the consent of individuals; even families, on Locke's account, originate in freely made contracts between individuals. Because all social groupings originate in consent, Locke is able to reject the claims of divine right of kings and patriarchal rule. Thus, all human groups come from free individual choice. Such a system clearly points to democratic governance, and it is a mere step from Locke's discussion of consenting to government to the argument that all government must operate by consent, or democratically. Americans have the tendency to think of themselves in Lockean terms, the popularity of legalistic thinking in American life being merely one symptom.

Individualistic contracts are problematic for at least two reasons. In the first place, Lockean contract theory minimizes the social nature of man as well as the extremely deterministic nature of his place in the social order. Individuals do not choose to be members of any political community in any foundational way. While we have the freedom to exit, the freedom to enter is much less clear. Most of us enter our political communities through our families, and our decision to enter the familial social grouping is even less freely made. While in extreme cases we may be able to escape our current families, we have no control whatsoever over who our ancestors are.

Cemeteries remind us of the fundamental sociality of human life because they root us in a particular place for eternity. One's ancestors are buried in the place they died, which is very often the place they lived. Thus, cemeteries are a counter to the geographic mobility of democratic life. At the same time, they oppose the vertical mobility of democratic life by binding us to our roots, however humble. Vertical mobility is challenged as well by the aristocratic nature of cemeteries; people are laid to rest with epitaphs indicating their triumphs, with large obelisks or small stones. While death may be the final equalizer, how we are remembered is still an indicator of the inequalities present in life. More importantly than these limits on mobility, cemeteries reject the radical individualism of Locke's account of human life, reminding us that families are the primary building block of social and political structures, not individuals. People live in families, and they are buried as 
families. The organization of cemeteries, with graves organized in family plots, and then the cemetery itself organized around the village or town in which it lays, is a physical symbol of the social organization of human life in general.

This family-centric view of the social compact is hardly new. Edmund Burke outlined what he considered to be the real social compact (as opposed to the individualistic social contract lauded by the French): an intergenerational compact between the past, the present, and the future. Burke changes the meaning of contract, negating the implied individualism, and instead grounding the contract in the generations: "Each contract of each particular state is but a clause in the great primaeval contract of eternal society, linking the lower with the higher natures, connecting the visible and invisible world, according to a fixed compact sanctioned by the inviolable oath which holds all physical and all moral natures, each in their appointed place". For Burke, then, society represents the high and low of man's nature, the balancing act between vice and virtue, individualism and sociality, between force and choice.

This contract between generations is necessary in part because the ends of society cannot be accomplished by one generation alone: "As the ends of such a partnership cannot be obtained in many generations, it becomes a partnership not only between those who are living, but between those who are living, those who are dead, and those who are to be born". Human greatness requires generations upon which to build, and that gradual building requires that we recognize the limitations of our own generation and how much we have relied on others who came before us. Thus, the proper understanding of contract for Burke is one that ties us to the society as a whole, and in which our present options are limited and hemmed in by our obligations and duties to the past and the future.

Cemeteries make physical what might otherwise be mere speculative platitudes. In a mundane way, we are obligated to care for and tend the graves of those who have passed, but this physical care is but a small part of what we owe to previous generations. The passing on of traditions, manners, and mores, and the proper establishment of the ideals of the past are the less obvious duties we owe to past generations. Cemeteries, as a gathering place where past meets present, remind us of our obligations, and can be a catalyst for contemplation amidst the bustling of democratic grasping.

Moreover, the impact of cemeteries is emotional, not rational, and their emotional impact is their strength. Graveyards impact us emotionally because the bond between generations is an emotional bond rather than a rational one, just as our attachments to our families are emotional rather than rational. Those like Ayn Rand and other radical libertarians, who approach political life from a purely rational perspective, would find it impossible to justify the bondage of the present to the past. Yet, when we look at gravestones and trace the names of families back for generations, emotionally this kind of bondage of one generation by another makes sense, in large part because we feel that we owe something to those who came before. Cemeteries remind us of a natural order innately understood but individualistically indefensible.

A related consequence of Lockean individualism (and the liberal democracy that follows) is that it privileges the present generation over the past. Democracy rooted in individual contract places the highest emphasis on the free choices of those who live now. Jefferson was one of the most outspoken defenders of this preference for the present, arguing (in the context of debt), "Funding I consider as limited, rightfully, to a redemption of the debt within the lives of a majority of the generation contracting it; every generation coming equally, by the laws of the Creator of the world, to the free possession of the earth he made for their subsistence, unencumbered by their predecessors, who, like them, were but tenants for life". Jefferson's Lockean approach dictates the passing on of power to the present generation, unhindered by the past (whether Jefferson sees the present generation as having an obligation to the future is unclear). Yet Jefferson himself is forced to recognize the limits of the present when he considers the great debt every free society has to the generations who came before. Jefferson is clear that education in the norms and values of freedom is absolutely necessary to the creation and maintenance of free government. He argues that the education required for self-government requires "education of what is right and what wrong; to be encouraged in habits of virtue and deterred from those of vice", and that above all the people must be taught to follow truth rather than error. Yet, Jefferson believes this education to be a multi-generational one, the "operation of a generation or two at least, within which period would have succeeded many Neros and Commoduses, who would have quashed the whole process". This, then, is the problem of free government: It requires educated citizens who have been passed down the habits of self-rule and virtue, but such education is constantly threatened by "Neros and Commoduses" (and later, Bonapartes and Iturbides). Jefferson acknowledged himself as confused about how to solve the problem of civic virtue as anyone else. Burke's answer to Jefferson's confusion is the intergenerational compact.

The policy of inheritance from previous generations, whether of property, virtues, manners, or rights, is "the result of profound reflection, or rather the happy effect of following Nature, which is wisdom without reflection, and above it". The debt we have to previous generations is a natural one, one which supports all life and which, fortunately, does not require our rational exposition, merely 
our internal feelings of right. While the desire to bury and pay homage to our dead may not hold up to rational costbenefit analysis, it is a profoundly natural desire and one that serves to link our higher and lower natures, this world and the next. The recognition that humans are linked, dead to living to not-yet-born, recognizes the reality that transmission of ideas, of principles, of right, must happen over generations. Thus, there is a very real sense, which even Jefferson is forced to recognize, that the generations are bound together for the purposes of education in right and wrong, for the passing down of traditions of selfgovernance, and the mental discipline to determine truth from error. These lessons are not and cannot be the outcome of a single generation. Caring for the past, and being thus limited by the dead, is a very real part of any political community.

Cemeteries help us recognize this debt, not only because we are forced to care for them, but also because cemeteries themselves transmit the lessons and principles that our society wishes to privilege. Gravestones tell us stories of love, honor, patriotism, service, and sacrifice. The "loving husband" and "beloved child" tell us less about an individual's character (biased as they are by grief), and more about traits those who buried him valued. Epitaphs are the ideals toward which we strive, and that we have carved these ideals into stone over countless generations attests to the permanency of these moral principles. Soldiers are described as courageous, infants as innocent, young men and women as beloved, cheerful, dutiful, or determined, and husbands and wives as faithful and loving. Even stones without epitaphs tell us the web of relationships in which this person existed, and remind us of the importance of those webs for human life. Gravestones are the moral signposts, carved in stone, that point us toward and back to the morals and values of our society.

While cemeteries can form a link in the chain of gradual human improvement, they also offer a more moderate, somber reflection on the possibility of radical human progress. Cemeteries serve to counter the progressive utopianism in democratic societies, gently reminding us that the problems facing society have not and will not change radically over time. Tocqueville provides a humorous account of an American life: "In the United States a man builds a house to spend his latter years in it, and he sells it before the roof is on: he plants a garden, and lets it just as the trees are coming into bearing: he brings a field into tillage, and leaves other men to gather the crops: he embraces a profession, and gives it up: he settles in a place, which he soon afterwards leaves, to carry his changeable longings elsewhere". Tocqueville traces this restlessness to American's desire for "worldly welfare", but then acknowledges an even more ultimate cause. The equality of conditions made possible by and elevated in importance by democracy ultimately spurs men on to greater and greater levels of effort. The democrat's desire to keep up with the neighbors results in great wealth for the nation, but an exhausted, often disappointed populace. The problem with equality as a principle is that it has no set end point, and thus "the desire of equality always becomes more insatiable in proportion as equality is more complete". Equality, unlike liberty, is like the horizon: "It perpetually retires from before them, yet without hiding itself from their sight, and in retiring draws them on. At every moment they think they are about to grasp it; it escapes at every moment from their hold. They are near enough to see its charms, but too far off to enjoy them; and before they have fully tasted its delights they die". The reason for this, of course, is that "whatever efforts a people may make, they will never succeed in reducing all the conditions of society to a perfect level". Equality comprehends too many different possibilities, and therefore the principle of democracy slowly becomes expanded into the progressive ideal of equality which is never attained but always sought.

Burke recognized this restlessness in his contemporaries (particularly the French), and sought to temper it by looking back to the past: "A spirit of innovation is generally the result of a selfish temper and confined views. People will not look forward to posterity, who never look backward to their ancestors". Those who believe in the inevitability of progress are often those most ignorant of the past. The constant restlessness and pursuit of a progress of democratic peoples is countered by the reality of cemeteries and the tragedy they represent. The most poignant headstones in cemeteries are topped by lambs, indicating the death of a child, but all headstones represent loss, tragedy, and the grief of a particular family. Cemeteries tell stories of war, of epidemics, of accidents, of illness and old age, and these stories force us to recognize the impermanence and impotence of the human condition. While progressive democracy believes equality can cure society's ills, cemeteries point to the past and the future at the same time. The contingency of human life is never eradicated, and cemeteries are an eternal reminder. These reminders are often necessary, since those in the present generation are often raised to believe themselves impervious to the dangers faced by previous generations; like Burke's innovators, they believe the past to be irrelevant. The present generation (like every generation before it) needs reminders it cannot ignore. In a crematorium world, we would never know that others have lived or died, nor what they lived or died for. In a world with cemeteries, we realize how much our fates are linked with those of the dead.

The stories cemeteries tell are not only those of the general run of human history; cemeteries offer another benefit to the political community by particularizing history, 
and providing us with the history of specific persons, not just a people. This particularization provides a counter-weight to the dehumanization of Lockean contract theory and democracy. The radical individualism of contract theory, at the same time that it frees individuals from the chains of political despotism, also frees humans from the specific traits or characters that make them distinct from their colleagues. The political theory that argues that all men are equal in their rights and that no man has the right (coming from ability or power) to rule over others without their consent is the same political theory that turns humans into identical, faceless beings who all share identical rights. For political purposes, no characteristics of individuals, other than rights, matter. The individuals is thus stripped of what makes him an individual and his individuality is replaced with universal rights that make him indistinguishable from anyone else in the political community. While the political benefits of universal rights are clear, and the desire to make other characteristics (such as bloodline and wealth) meaningless for purposes of consent laudable, the rejection of defining characteristics can lead to a rejection of greatness and, oddly enough, to the loss of value of human life as a whole. Nietzsche famously decried democracy, crying out, "to us the democratic movement is not only a form of the decay of political organization but a form of the decay, namely the diminution of man, making him mediocre and lowering his value". He then goes on to ask: "Is greatness possible?" Nietzsche's rejection of democracy and its focus on equality is based on the leveling effect of democracy on human greatness, and the subsequent reduction of humans to beings who are not worthy of being preserved. If humans are indistinguishable and interchangeable, then the argument that one particular human has any worth becomes difficult to sustain. Nietzsche's goal is to resurrect that which is worth preserving in human life, rather than focusing on the the "low but solid" base that all humans share.

Nietzsche was not alone in his concern about the leveling effect of democratic liberalism. Half a century before, Tocqueville argued, "Nowhere do citizens appear so insignificant as in a democratic nation.... In democratic communities the imagination is compressed when men consider themselves; it expands indefinitely when they think of the State". The equality provided by democracy diminishes individuals, leaving them unsure of their own powers and willing to trust the power of the state. Equality thus forms the foundation for despotism. History soon becomes the history of nations, without reference to individuals great or small. Tocqueville urged against this tendency to ignore the potential of individuals: "It would seem as if the rulers of our time sought only to use men in order to make things great; I wish that they would try a little more to make great men". Great men are the foundation of a great democracy, because it is they who appreciate liberty, prevent the encroachments of govern- ment, and provide an example to future generations to build upon.

Cemeteries act as a barrier to the reduction of individuals to indistinguishable beings. A graveyard adds particularity to our understanding of history. Instead of nations, wars, epidemics, and statistics, we see men and women, soldiers, and children. This particularity provides us with a context and helps us understand history as lived by individuals. Citizens see these individuals surrounded by their families, linked together as links on a chain, stretching backward and forward in history. Through their epitaphs (however inflated) we see their livelihoods, their connections to the community and family, and ultimately, their importance, in whatever small way, to those around them. Instead of understanding men through universal principles, we can understand them through the particular, concrete aspects of their lives. As Chantal Delsol argues against universal human rights, "...men can only live in the concrete". Cemeteries provide a reminder of the concrete and the particular, and a reminder of the power of individuals. The pilgrimages made to the graves of the famous testify to our desire to not forget the accomplishments of those who have passed. How much easier would it be to forget if their graves did not exist?

Cemeteries then offer one, albeit minor, counterweight to the modern democratic project. In their small and quiet way, graveyards and their inhabitants link us to the past and force us to remember. They help us understand the intergenerational obligations we have to one another through inheritance of morals and ideals, and their presence is a reminder of the innate, emotional bonds we share with one another, which are at the same time natural and fragile. Their presence prevents us from promoting the present generation at the expense of all others, because while democracy privileges the present generation, cemeteries privilege the past. Until democracy can do away with these reminders of the past, or make them utterly irrelevant, the triumph of modernity will not be complete.

Yet there is no doubt that eventually our ways of dealing with the dead will increasingly leave no trace. Should this shift become complete (the use of lye, where bodies are dissolved and then unceremoniously dumped down the drain, has become one publicized option), it may represent the final triumph of democratic egalitarianism and the complete sovereignty of the present generation. The loss of cemeteries will be both cause and symptom of this triumph; the decreasing care for cemeteries over time will make them less and less important in the public's estimation, and this decreasing importance will lead to more neglect, which will in turn cause us to minimize or forget altogether the foundational lessons they offer.

Still, there may be hope. While a crematorium (or lye) society may still be in our future, the desire to be 
memorialized and remembered will hardly die away. The strength of cemeteries is their permanency, protected as they are by the emotional weight of their inhabitants. While some municipalities (Chicago most notably) turned cemeteries into stadiums and parks (acts that occurred, hardly coincidentally, during the Progressive era of the late 19th and early 20th centuries), most cemeteries are today protected by the emotional connection we still have with the dead, and it is that emotional connection, the connection we share due to our nature as humans, that links us to an intergenerational compact. Apart from our emotional connection to the dead, cemeteries are meant to be durable; whatever one thinks of the environmental degradation involved there is nothing more permanent than embalming a body, encasing it in lead, and burying it under a marble slab. None of that is going anywhere, and that is precisely the point. Even without lead and embalming fluid, the very act of burial leaves a trace. It ties us to the past by changing the landscape of the present.
In the end though, cemeteries are potent reminders of our fractured psyche; that our progressive democratism must share space with the remnants of aristocracy and religion. Such a balance is not an easy one, and cemeteries create problems of their own, taking up land, causing environmental damage, and funneling money away from the projects of the present generation. The existence of cemeteries needs to be justified, and it is, usually on historical or cultural grounds. But the primary justification of cemeteries is the emotional, foundational "wisdom without reflection" that prods us to recognize the continuing relevance of the dead. This justification is not rational or reflective, and thus might seem weak in the face of modern ratiocentric policy making. But it is a testament to the power of that prereflective wisdom that we still, after centuries of liberal democracy, recognize the need to remember.

Lauren K. Hall is assistant professor of political science at the Rochester Institute of Technology. 